\title{
The Development of Appreciative Prose
}

\section{Textbook through Active Learning for Students of PGSD Study Program in Surakarta Regions}

\author{
Markamah, E.S., Slamet, S.Y., Rukayah, Winarni, R.
}

\author{
Sebelas Maret University, Surakarta, Central Java, Indonesia
}

\begin{abstract}
Literary learning has not been taught appreciatively to PGSD students. It is urgent and needed to be done research on the development of appreciative literary textbooks. The purpose of this study is to: (1) describe the needs of students and lecturers about thematic-integrative appreciative prose textbook, (2) to describe the development of thematic-integrative appreciative prose textbook, (3) to find the effectiveness of thematic-integrative appreciative prose textbook, and 4) describe the result of dissemination of thematic-integrative appreciative prose textbook. The type of research used in this study was a development study developed by Borg and Gall. The study was conducted through 4 steps, namely: (1) preliminary stage, (2) model development stage, (3) model testing stage, (4) dissemination stage. The research approach used in the exploration stage was descriptive qualitative approach. Data were collected through interviews, observation, documentation, and questionnaires. Data analysis technique was done using interactive analysis model. Model testing was done by conducting experimental research. The results of this research were: (1) exploration stage showed that appreciative prose textbook that was used in UNS Surakarta, UMS Sukoharjo, and UNISRI Surakarta did not meet the students and lecturers' expectation, (2) development stage of thematic-integrative appreciative prose textbook model was done through preliminary field testing; and (3) the effectiveness testing of the textbook (main field testing) found out that the value of t obtained (8.85) which was then compared with the value of t table for $N=90, \alpha=0.05$ (1.67). Thus, t-obtained (8.85) > $t$ table (1.67), then the hypothesis was accepted (Ho was rejected) and the study is significant. This means that thematic-integrative appreciative prose textbook is declared effective.
\end{abstract}

Keywords - active learning; textbooks; appreciative prose learning; development; thematic integrative.

\section{INTRODUCTION}

Conditions that occur in the study of literature in PGSD study program were still not encouraging. It was important to make efforts to develop textbooks of literature learning that is appreciative based on thematic integrative through active learning. Appreciative literature textbooks are expected to be more appropriate, in accordance with the needs, and characteristics of students, so it can help to improve students' literary appreciation skills.

The phenomenon of less successful literature learning in PGSD can be said mostly caused by the low level of students' ability in appreciating literature. This is due to, among other things, the limitations of textbooks as a reference. Raw materials that could be used to learn literature appreciation is inadequate. Lecture books that exist or commonly used have not fully support the success of student literacy appreciation learning.

Mustakim's research (2010) showed that learning literature appreciation in schools was limited to literary understanding, had not contained the ability of inferential, evaluative, and appreciative. This could not be separated from the general fact that literary learning in schools were still talking about literature, memorizing the work, and the implementation of learning through lectures. The problem was that frequent learning of literature had not been able to make students to have an understanding of the beauty of literature and the main purpose of literary learning.

Another problem encountered was that the learning process was still conventional. Learning was dominated by lecturers, lack of adequate teaching materials and the presentation was not in accordance with the interests and conditions of students, which caused the level of appreciation to be low. One reason that these problems occurred because of the teaching materials presented was not appropriate to the existing context.

Active learning is activities that help students to test their feelings, values, and behaviors (Silberman, 2004: 5). Silberman describes the moment of active learning as students do a lot of activities. They use their brains to learn ideas, solve problems, and apply what they learn. According to Lorenzen (2001: 19) active learning is a method of educating or inviting students to participate actively in the classroom. Active learning aims to optimize the use of all potential possessed by students, so that all 
students can achieve satisfactory learning outcomes according to their personal characteristics. In addition, active learning also aims to keep the attention of students to stay focused on the learning process. Therefore, appreciative literary learning needs to be conducted using active learning.

Good literary learning should be able to improve students' language skills, enhance cultural knowledge, develop inventiveness and taste, and support character formers (Moody, 1971: 15). The purpose of the literary study was for the learner to be able to enjoy, understand, and utilize literary works to develop personality, broaden life insight, and improve knowledge and language skills (Nurhidayati, 2011,87 ). The main purpose of teaching literature is to provide the opportunity for the learner to gain literary experience with the ultimate goal of being able to appreciate the literature (Gani, 1998, 15). The fact shows that literary teaching undertaken in schools had not been fully able to meet these goals and functions.

Seen from the value of education, literature has the benefits of (1) accelerating language development, through listening and reading of literature, (2) developing writing skills, because there is a correlation between reading skills possessed and writing skills; and (3) developing crosscurriculum skills, through learning various knowledge through literature (Supriyadi, 2006: 9).

Based on the results of interviews with students and lecturers, the ability to appreciate the literature of PGSD students as prospective elementary school teachers has not succeeded optimally. The lack of success is due to the lessappreciative and integrative learning strategies. Literary appreciation learning is taught through memorizing the names of authors and poets as well as their works. Literary appreciation learning has not yet arrived at enjoying, appreciating, valuing, and utilizing literary works to develop personality, broaden life's insight, and improve language skills.

Based on the current learning facts that exist in PGSD study program, it was shown that students have not immediately introduced and familiarized with the work of literature. This activity should make students directly recognize, understand, and can appreciate Indonesian literary works and communicate it orally and/or in writing. The enjoyment of literature in earnest can foster understanding, appreciation, critical sensitivity of mind, and the sensitivity of a good feeling to the literary work. Communicating activities can be linked to the activities of discussing, reclaiming, making, writing, and so forth.

In learning language and literature, integrative concept refers to the understanding of the presentation of learning materials of language and literature in an integrated manner. Mathematics material (structure and vocabulary) with skills (listening, speaking, reading, and writing) in the implementation of learning activities, the presentation of the material presented in an integrated or integrative. Literary listening activities can be integrated with speaking activities, for example, retelling, frequently asked questions, discussion / soliciting feedback. In addition, listening activities can be integrated with reading, writing, or even four language skills at once.

The success of appreciative and integrative literary learning cannot be separated from the existence of textbooks. As one source of learning, textbooks are expected to answer the needs of students in learning, providing convenience to students in obtaining some information, knowledge, experience, and skills. Textbooks are also expected to be a means of opening the way that can open the students' horizons to the teaching and learning process that will be followed.

Textbooks which contain specific materials are used as a teaching and learning guidance at school (Richards \& Rodgers, 2002: 550). Textbooks are usually used in conjunction with other learning resources such as workbooks, teacher reference books or supporting texts (Tomlinson \& Masuhara, 2008: 14). For the purpose of fulfilling prose textbooks that are appreciative based on thematic integrative appraisal, this research is urgent and needs to be done in Undergraduate degree of PGSD Study Program in Surakarta area.

\section{RESEARCH METHODOLOGY}

The type of research used in this study was a development study developed by Borg and Gall (2003: 772). Furthermore, Borg and Gall said that research and development is a process used to develop and validate educational products. Seals and Richey (1994: 75) suggest that development research as a systematic review of the design, development and evaluation of programs, processes and learning products which must meet the criteria of validity, practicality and effectiveness. Plomp (1999: 35) adds a "can indicate value" criterion.

According to Borg and Gall (2003: 775-776), the steps of research and development include 10 steps, namely: (1) preliminary study, (2) research planning, (3) design development, (4) preliminary field test, 5) revision of limited field test results, (6) main field test, (7) revision of broad field test result, (8) feasibility test, (9) final revision of feasibility test, (10) dissemination and implementation of final product. The ten steps are divided into 4 main phases, each of which includes several operational steps. The four steps are; (1) the introduction stage, (2) the model development stage, (3) the model testing stage, and (4) the dissemination and implementation stage of the model (Sukmadinata, 2010: 182- 189; Nurkamto, 2012: 2-5).

The exploration stage was done in-depth study on the implementation of thematic integrative oriented 
appreciative prose learning in PGSD Study Program in Surakarta. The purpose of this activity was to analyze the needs of students and lecturers on textbooks of appreciative prose learning based on thematic integrative that is considered able to increase the students' ability to appreciate student prose optimally. The research approach used was qualitative descriptive approach. Researchers emphasized the observation on the interaction between students and lecturers in the implementation of prose appreciation learning in the research location. Researchers also conducted interviews and questionnaires to students and lecturers, and analyzed documents related to research problems.

The data of this study were obtained from various data sources available at the study sites. Types of data sources used were: 5 students and 5 lecturers, events of prose appreciation learning activities in the classroom, and documents or archives. Data collection techniques used were interviews, observation, documentation, and questionnaires. Data analysis of this research data was done by interactive analysis model (Miles and Huberman, 1992: 16-20; Sutopo, 2002, 95-96), conducted in 2 stages: during data collection and after data collection.

In the model development stage, the main objective was the creation of thematic integrative oriented appreciative prose learning textbook model. The development of a prototype textbook model was done in the form of a cycle, which is a blend of research and practice (Gall et al, 2003: 578). The steps taken include: preparation of prototype, implementation, evaluation of implementation, and revision in a sustainable manner. The procedure used is the Glanz model theory guide (in Gall et al, 2003: 585-590), which includes: data collection, analysis, data interpretation, reflection, and modification. The next cycle is done with the same procedure. In addition, the ZuberSkeritt model is also used (in Cohen, 2000: 235), which includes: careful planning, planned planning, observation, assessment, evaluation, critical analysis of implementation results, and subsequent cycle determination.

The form of development wa done by way of testing the draft textbook model in the field through limited trials and extensive trials. A limited trial was conducted on the Undergraduate Program of PGSD UMS Sukoharja. Extensive trials were conducted on the Undergraduate Program of PGSD UNS Surakarta and UNISRI Surakarta.

Data collection techniques used were in-depth interviews, participant observation, document analysis, tests, and focus group discussions. Data analysis was done in two ways, qualitatively and quantitatively. The model that has been tested is then consulted to the expert, Dr. Nugraheni Ekowardani, M.Hum., lecturer of Sebelas Maret University Surakarta, with the aim that the developed textbook model has substantive truth and the quality can be validated.

The model testing phase aims to test the effectiveness of thematic-integrative oriented appreciative prose learning textbook model in improving the students' ability in appreciating prose. Model testing was done by conducting experimental research. The type of experimental research used is quasi-experimental research. The experimental research design chosen was Non-equivalent Quasyexperimental Design Model Before-after Design (Wiersma, 1986: 143-144; Cohen et al. 2000: 216; Sugiyono 2012: 302-305). The experimental procedures used were the concepts of Gall, Gall, \& Borg (2007: 381) and Cohen (2000: 216).

The experiment class was 90 students of PGSD UNS Surakarta. The control class was 85 students of PGSD UMS Surakarta. This study would see the main effect of thematic-integrative oriented appreciative prose learning textbook to the students' ability in appreciating prose.

Technique of collecting data used was test on the ability to appreciate prose. The analysis of the research data was done through two stages, namely the requirements analysis test stage (normality test, homogeneity test, and balance test) and the data analysis stage to test the effectiveness of the model, ie by the mean difference test (independent test). The output of the model testing phase was an experimental textbook of thematic-integrative oriented appreciative prose learning that has been tested in process and in product.

This dissemination stage was done through publishing thematic-integrative oriented appreciative prose learning textbook that has been developed with the hope that the textbook can be implemented on learning prose especially in univercities which have Undergraduate Program of PGSD. Dissemination was done through national seminars and through the writing of articles in international journals, as well as the issuance of Proactive Book of Proactive Learning Text based on thematic integrative which has ISBN.

\section{RESULT AND DISCUSSION}

\subsection{Exploration Stage}

Through the analysis of the syllabus document and the Lesson Plans (RPP) prepared by lecturers it was found that prose appreciation learning did not stand alone as a course, but only became part of the course in Indonesian Language and Literature Learning for Elementary School. The average prose appreciation learning was taught for 2-4 meetings of 14-16 meetings planned by the lecturer. This was understandable because the material of prose appreciation is only a subset of extensive literary learning materials. According to the researchers, prose appreciation learning should be given a more important portion or even 
standalone in a course. This is with the aim that literary learning can be taught in an appreciative and problematic approach. Based on the observations that researchers did on prose appreciation learning, it was obtained that prose appreciation learning was centered on lecturers and theoretical, lecturers taught prose appreciation mechanically. The ability of the students in prose appreciation was limited to a theoretical understanding and has not yet reached a meaningful and appreciative prose appreciation.

Based on interviews with lecturers, it is known that lecturers of literature learning had done prose appreciation activities with various strategies, but the results had not been satisfactory. The learning of prose appreciation had not been done using appropriate textbooks yet; most still in the form of tasks. In order to know the needs of lecturers to textbooks of prose learning that appreciative, interviews was conducted on five lecturers at three universities that served as research sites. In the interview, it was known that the lecturers and students needed appreciative prose learning textbook based on thematic integrative.

\subsection{Model Development Stage}

3.2.1. The development of prototype model into textbook of appreciative prose learning based on thematic integrative The results of exploratory studies were the empirical basis for the development of textbook models. Based on the results of exploratory studies, the next step is to do literature study. The literature study was conducted with the aim of obtaining a conceptual basis for an appreciative prose textbook to be developed. Once the empirical foundations and conceptual foundations have been completed through exploratory studies and in-depth literature studies, the next step is to compose a prototype thematic-integrative oriented appreciative prose learning textbook.

The prototype of prose-themed textbook model contains: (1) literary nature, (2) understanding of prose, (3) prose appreciation, (4) integrative thematic learning, and (5) active prose learning. The thematic integrative oriented appreciative prose learning textbook model was implemented in a Semester Learning Plan (RPS) and Lesson Plan (RPP) of Indonesian Language and Literature Elementary Learning Course, specifically on prose appreciation study materials. The Lesson Plan (RPP) was prepared for six meetings, each meeting with a time allocation of $2 \times 50$ minutes. (2) encouraging the active participation of students, (3) developing a culture of reading and writing, (4) providing feedback and follow-up, (5) giving linkages and integrity, and (6) implementing information and communication technologies.

The prototype of textbooks that have been prepared was then presented in focus group discussions to get input from the participants. In the focus group discussion, some participants provided input. The inputs were recorded and the inputs considered to be good were used as materials for improving the prototype model.

\subsubsection{Development of Prototype Textbook Based on Expert's Judgment}

Prototype of thematic integrative oriented appreciative prose learning textbook was then validated through Expert Judgment. This was done with the aim that the developed textbook has substantive truth and the quality can be accounted in terms of scholarship. This expert assessment activity was done before the model prototype was tested. Results of discussions with experts and inputs from experts were used as a reference to make improvements to the learning model developed. Expert selected to validate the model was: Dr. Nugraheni Ekowardani, M.Hum., Lecturer of Sebelas Maret University Surakarta. The output of this stage is an integrative thematic-based, apresiatif-based textbook that has undergone improvement based on the advice given by experts.

\subsubsection{Development and Improvement of Textbook Prototype Based on Limited Test}

A limited experimental test of thematic-integrative oriented appreciative prose learning textbook was conducted in undergraduate students of PGSD UMS Surakarta. The trials were conducted in three stages, each stage consisted of two meetings, and each meeting lasts for 100 minutes (2 SKS)

Based on the analysis of the results from the limited trial in three stages (6 sessions), it was found that the thematicintegrative oriented appreciative prose learning textbook is suitable to be applied in prose appreciation learning. Based on the observation of the researcher, the implementation of thematic-integrative oriented appreciative prose learning textbook has been in accordance with the structure of textbook that has been set. In addition, the effective development of students during the course of study showed an average score of 3.71 , in very good category.

According to students, thematic-integrative oriented appreciative prose learning textbook makes learning more interesting, effective, and fun because there is an appreciation activity and not just crammed with literary theories. According to the lecturer, the application of this textbook in prose appreciation learning uses active learning, so that all students are actively involved in the learning process.

Procedural weaknesses during limited trials are described as follows: (1) in prose appreciation activities, students cannot concentrate fully because there is no reference book, (2) in the discussion to find the constraints contained in the appreciation activity, the students were not brave enough to show their opinion (3) prose appreciation 
activities cannot be done well by the students because their appreciation ability was still weak, (4) the ability of students to appreciate the prose was still weak, especially in the prose study, it has not been mastered properly. Some of the weaknesses found in these limited trials were used to improve the textbooks that were piloted in the classroom. Improvements are emphasized primarily in procedures for the implementation of prose appreciation.

\subsubsection{Development and Improvement of Textbook Prototype Based on Main Test}

Extensive trials were conducted on two university students, students of Undergraduate Program of PGSD UNS Surakarta and Undergraduate Program of PGSD UNISRI Surakarta. Extensive trials were conducted in 3 stages, each stage consisting of two meetings and each meeting lasts for 100 minutes (2 SKS).

During extensive trials in 3 stages (for 6 meetings), careful observation on the behavior of students, lecturers, and at each stage of the trial was conducted. Based on the observation, thematic-integrative oriented appreciative prose learning textbook has several advantages, they are: (1) this textbook is able to create new learning atmosphere that is effective and fun for students, students have more spirit to appreciate prose and discuss the result, (2) this textbook is able to encourage students dare to try to appreciate prose without fear of wrong and give response to the result of their prose appreciation, (3) students are also trained to improve the prose appreciation, (4) this textbook trains students to develop the activity of learning through prose appreciation activities optimally.

Some of these procedural weaknesses and deficiencies are used to improve the textbooks being piloted. After the improvement, the researcher assigned the draft textbook model to be a thematic integrative-oriented prose learning textbook.

\subsection{Dissemination Phase}

This dissemination stage socialized thematic integrativeoriented appreciative prose learning textbook in the hope that the textbook can be implemented on prose appreciation learning at Univercities which has Undergraduate Program of PGSD Surakarta. Dissemination was done through national seminars, writing articles in international journals, as well as publishing thematic-integrative-oriented appreciative prose learning textbook. In addition to socialization, acceptance of textbooks developed was also tested. Acceptance test was done through assessment and responses from seminar participants on thematic integrative-oriented appreciative prose learning textbook that has been developed. The results of the seminar participants' evaluation of the textbook showed that textbook developed was accepted by lecturers, policy makers, and students at the PGSD Study Programs in Surakarta.

\section{CONCLUSION}

Based on the research results, it can be concluded as follows. First, research in the exploration stage produces the following conclusions: (1) the existing book is still theoretical, (2) the lecturers of the subjects of literary learning have good competence to enhance prose appreciation learning, (3) the majority of students find difficulties in appreciating prose, (4) prose appreciation learning has not been done appreciatively, (5) students and lecturers need textbook of prose learning that is appreciative with thematic-integrative basis. Secondly, prototype of thematic-integrative-oriented appreciative prose learning textbook model contains literary essence, understanding of prose, prose appreciation, integrative thematic learning, and appreciative prose learning.

The model prototype was further piloted in limited trials and extensive trials. Third, model testing is done through experimental research. Based on data analysis with difference test of two average (independent t-test) found out that thematic-integrative-oriented appreciative prose learning textbook was more effective compared to the former textbook in improving the students' ability in appreciating prose for PGSD Undergraduate Study Program in Surakarta region. Fourth, the dissemination stage is socialization process of thematic-integrativeoriented appreciative prose learning textbook through international journals and publishing thematic-integrativeoriented appreciative prose learning textbook. In addition to socialization, test of acceptance was also conducted through the assessment and responses of seminar participants toward thematic-integrative-oriented appreciative prose learning textbook developed. The result indicates that the thematic-integrative-oriented appreciative prose learning textbook is acceptable to lecturers, students, and policy makers.

\section{REFERENCES}

[1] Borg, Walter R. dan Gall, Meredith Damien. 2003. Educational research: An Introduction. New York: Longman.

[2] Cohen, Louis et al. 2000. Research Method in Education. Great Briatin: TJ International Ltd, Padstow, Cornwall.

[3] Gall, Meredith D., Gall, Joice P.; W.R. Borg. 2007. Educational Research. Boston: Pearson Education. Inc.

[4] Lizt, D.R.A. 2005. Tectbook Evaluation and ELT Management: A Shout Korea case Study, Asian EFL Journal Online. Available at http://www.asian-elfjournal. com/Lizt_thesis. 
[5] Lorenzen, Michael. 2001. Active Learning and Library Instruction (Online) dalam http://www.libraryinstruction.com/link.html. Diunduh pada 23 Mei 2017.

[6] Miles, Matthew B. dan Huberman, A. Michael. 1992. Analisis Data Kualitatif. (terj. Tjetjeo Rohendi Rohidi)). Jakarta: universitas Indonesia.

[7] Moody, H.L.B. 1971. The Teaching of Literature. London: Longman.

[8] Nurhidayati. 2011. "Pembelajaran Menyimak Apresiasif Cerita Pendek dengan Strategi Belajar Kooperatif'. Litera. 10. (1): 87-99.

[9] Nurkamto, Joko. 1012. "Struktur Penelitian danPenulisan R \& D Bidang Pendidikan (Versi Borg dan Gall)". Makalah Kuliah Umum Program Pascasarjana IKIP PGRI Madiun : 30 September 2012.

[10] Plomp, Tj. 1994. 'Educational Design: Introduction”, dalam Tjeerd Plomp (ed). Educational \& Training Systen Desing: Introduction Desing of Education and Training. Utrecht: Lemma. Nederlands. Faculty of Educational Science and Technology, University of Twente.

[11]Richard, JC \& Rodgers T. 2002. Approaches and Methods in Language Teaching. Cambridge: Cambridge University Press.

[12] Seals, Barbara B. \& Richey, Rita C. 1994. Teknologi Pembelajaran: Definisi dan Kawasannya (terj. Dewi S. Prawiradilaga dkk.). Jakarta: Kerjasama IPTPI LPTK UNJ.

[13] Silberman, Melvin. 2004. Active Learning; 101 Strategi Pembelajaran Aktif. Terj. Sarjuli, et al. Yogyakarta: YAPPENDIS.

[14] Sugiyono. 2013. Metode Penelitian Kuantitatif dan R $\&$ D. Bandung: Alfabeta.

[15] Sukmadinata, Nana Syaodih. 2010. Metode Penelitian Pendidikan. Bandung: Remaja Rosdakarya.

[16] Sutopo, H. B. 2002. Metodologi Penelitian Kualitatif. Surakarta: Sebelas Maret Univercity Press.

[17] Tomlinson,B. \& Masuhara (Eds). 2004. Developing Language Course Materials. Singapore: RELC Portfolio Series.

[18] Wiersma, William. 1986. Research Methods in Education.: An Introduction. Boston: Allyn and Bacon, Inc. 